Ellen McLarney

Assistant Professor

Asian and African Languages and Literature

Duke University

Box 90414, 227 Trent Hall

Durham, NC 27708

ellenmc@duke.edu 


\section{"EMPIRE OF THE MACHINE": THE ARABIC OIL NOVEL}

"Faced with the machine, the human being cannot maintain his equilibrium, until he himself nearly transforms into a machine."

Sayyid Qutb, "The America I Have Seen: In the Scale of Human Values"

"War is beautiful because it initiates the dreamt-of metallization of the human body." Filippo Tommaso Marinetti, "The Futurist Manifesto"

"If the internal combustion engine was the heart of the modern military machine, its life blood was oil."

Harold Williamson et al., The American Petroleum Industry

Mechanization of human life is the main subject of the oil novel, a genre that charts the explosion of industrial production in the remote regions of the earth. One of the products of this process is a vision of a pristine state of nature, one prior to and untouched by the predations of the "empire of the machine." This is a golden age, an imagined utopia, "the natural economy, the moral economy, the organic society, from which critical values are drawn... a contrast to the thrusting ruthlessness of the new capitalism." (Williams 36-7). These are motifs found not only in the Arabic oil novel, but also in Upton Sinclair's novel Oill, as well as in Latin American and African oil novels. ${ }^{2}$ The emphasis is on particular locales, valorized as cultural origins. Their aura of authenticity is envisioned as antithetical to the globalizing force of the military-industrial complex, or even as its antidote. But authenticity is clearly one of its byproducts. ${ }^{3}$ In the inexorable march of progress, is aura set up only to be destroyed? These narratives repeatedly reenact this destruction, synchronizing time to the machine of modernity.

This essay examines two seminal works in the canon of Arabic literature, Ghassan Kanafani's Rijal fi al-Shams (Men in the Sun, 1963) and 'Abd al-Rahman Munif's Mudun al-Milh (Cities of Salt, 1984). ${ }^{4}$ Kanafani and Munif project ideal communities back in time to pre-industrial utopias. They depict metaphysical, transcendent worlds, where man exists in harmony with his 
environment. These geographical locales are saturated with cultural meaning-an olive grove in a pre-1948 Palestinian village; Shatt al-'Arab in Iraq, where the Tigris and Euphrates meet and pour into the Persian Gulf; an oasis in the Arabian peninsula and suggestions of the mythical Najd of classical Arabic poetry. The authors bury the seeds of these cultural origins, scattered elements of tradition and the past, within the modern technology of the novel. As they dig down into their roots, Kanafani and Munif ground the Arabic novel in an "aura of authenticity," lending legitimacy to a genre some literary criticism has considered profoundly inauthentic. ${ }^{5}$ This is also a means by which these authors—-both products of their own exile—recapture lost lands that fuel their yearning. This racial, cultural, and geographical memory is at the core of their narratives: a throbbing, living heart planted deep in the soil. The anthropomorphic traits they infuse in the land have the effect of not only humanizing nature, but naturalizing humanity in geographic space. This has an ideological function of rooting a foreign genre in local soil, performing the function of criticizing imperial modernity, and producing "narratives of cultural continuity that can absorb the dislocations of modernity" (Mufti 88).

While these narratives begin with the heart, they climax with the metamorphosis of the human body into a machine-like entity. In Men in the Sun, Kanafani depicts a water tanker as symbolically aborting the vestiges of village life, then giving birth to the new denizen of the petroleum economy. Munif warns of a Sodom-like transformation of the human being into salt, but these pillars are oilrigs. Machines preside over-and embody — the ritualistic state of transition to the age of technology. Viciously tearing up olive groves and palm trees, they destroy centering logic of an agrarian existence. Apocalyptic imagery permeates these climactic scenes: the natural order is turned upside down; man falls from the garden; and paradise is lost. The world is abandoned by God, Lukács very definition of the novel (88). Arabic oil literature is not alone in its lamentation over the fall from the garden. In La novela del petróleo en Venezuela, Gustavo Luis Carrera describes the 
how the "empire of the machine" transforms the material and spiritual order of things: "El nuevo orden petrolero desplaza al hombre del sitio clave que ocupaba en la tradicional economía agrícolapecuaria" $(80,98){ }^{6}$ The "sitio clave" is the key space — traditional, agrarian, and natural — that the petroleum industry supplants. Kanafani and Munif begin with this key space, what Lukács describes as a transcendent locus (20). Kanafani and Munif dwell by the ruins, mourning the loss of their homelands while depicting the tortured birth of the mechanical age. Born out of the steel womb of trucks and iron pillars of oil pumps, this is no natural thing, but an alien presence in the land, an inorganic plant in the native soil.

Sayyid Qutb, in the epigraph above, warns about man becoming machine in the "violent struggle" to tame nature. The use of the weapons of science against "an untamed, stubborn virgin" led to what he calls the American's “deformed birth."7 Qutb sees this technological dominance not as the triumph of progress, but rather of materialism, brute force, and naked aggression that fuels a “hunger for war" (15). In Walter Benjamin’s essay on technological reproduction, he grapples with its destructive dimensions (although the essay is better known for his celebration of the creative possibilities of the mechanical age). Benjamin opens with art, but closes with war. The argument reaches a crescendo with images of "the horrifying features of imperialist war," vivid descriptions of the transformation of the natural landscape, the flowering meadow enriched with "orchids of machine gun fire," human streams in the beds of trenches, and bombs planted instead of seeds. "Imperialistic war," Benjamin writes in italics, "is an uprising on the part of technology, which demands repayment in 'buman material' for the natural material society has denied it" (121-2). ${ }^{8}$ The "shattering of tradition" that promised to emancipate the masses loses its creative potential. Instead, it becomes a form of murder. ${ }^{9}$ Kanafani and Munif dwell on the damage wreaked, lamenting the price paid in human life for oil hungry machines. 


\section{Mechanical Man: Men in the Sun}

Both Kanafani and Munif lived lives of exile, taking part in a massive wave of immigration to the Gulf during the oil boom. Since Gulf society lacked a well-developed bureaucratic middle class, educated labor was imported from countries like Egypt, Lebanon, and Palestine needed to manage new institutions and enterprises. Many of these immigrants became, like Kanafani and Munif, members of a new secretarial class from which a subgenre of Arabic oil literature began to emerge. ${ }^{10}$ 'Abd al-Rahman's Munif worked in the oil industry for nearly two decades and his earliest fiction engaged the politics of petroleum production. ${ }^{11}$ Cities of Salt, a five-volume chronicle of Saudi Arabia’s modern history, is his masterpiece. His Wadi al-'Uyun is a thinly disguised Abqaiq, an oasis that became one of Saudi Arabia's largest oil fields and the starting point of Trans-Arabian Pipeline (Tapline). ${ }^{12}$ Like Munif, Kanafani migrated to the Gulf, working as a schoolteacher in Kuwait for five years ('Abbas 146). Novelist and literary critic Radwa 'Ashur describes his experience: "There he knew exile in a new form: the loneliness of the stranger, the alienation of the isolated, the thirst of the psychical self in the desert" ("Ashur 23). Soon after his return from the Gulf, Kanafani composed his first novel Men in the Sun (A. Kanafani).

Kanafani and Munif depict civilizational bloodlines in literalist terms, expressing anxiety about cultural integrity. In The World, the Text, and the Critic, Said writes about such images of historical continuity, as "human history being generated, being produced and reproduced in the very way that men and women generate themselves by procreating and elaborating the species... Images for historical process are invariably biological" (Said 112). Said identifies these "ideas about repetition" with the reproduction and continuity of the gens, achieved through the naturalistic bonds of filiation, as opposed to the more institutionalized connections of affiliation. For Said, affiliation refers to alliances based on mutual economic interest in contrast to affective bonds of family, kin, race, blood, culture, religion. Both Men in the Sun and Cities of Salt open with birthing images, 
expressed as a fertile earth bringing forth its fruits. Kanafani and Munif employ agrarian metaphors of planting seed, soil erupting with life, and nurturing young shoots connect the land to human processes of reproduction. These symbols speak not just to the ecological relationship between humanity and the earth, but of an organic relationship between race and territory, culture and geographical space. The globalizing thrust of the industrial age appears to sever this cultural and historical specificity at its roots. Hence begins the process to recapture or re-imagine what has been lost, the salvaging — or salvation_-of a natural and organic community pre-dating the invasion of the foreigners and their machines.

One of the most powerful and moving scenes in Arabic literature is Kanafani's opening to Men in the Sun. The scene is situated in Shatt al-'Arab, the "Bank of the Arabs," the furthermost point where the Arab world meets the Persian Gulf. Literary critic Siddiq remarks that the "emphatic reference to Shatt al-'Arab draws attention to two interrelated points. The first is the 'Arabness' of this disputed area between Iran and Iraq. The second is the status of Shatt al-'Arab as the eastern border of the Arab homeland in the ideology and strategy of Arab nationalism" (Siddiq, 16). An erotically evoked filiation connects Shatt al-'Arab to Palestine, as Kanafani viscerally and corporeally links them. Images of planting and birthing overlap, emphasizing organicity and "natural" ties. After an overland journey from Palestine to Iraq, Abu Qays collapses on the ground and breathes in the damp earth.

The smell... surged into his head and poured into his veins ['uruq]. Every time he inhaled the smell of the earth while he laid on it [her], he imagined that he breathed the hair of his wife when she came out of the bathroom having washed her hair with cold water. That smell, that smell of a woman who had washed her hair with cold water and spread her hair on his face while it was still damp. The same throbbing [of the heart], as if you were tenderly holding between your palms a small bird $(7-8) .{ }^{13}$ 
Kanafani plays on the double meaning of 'uruq as both roots and veins, creating analogous images of body and earth. The interjection of the heart emphasizes the scene's affective core of love and intimacy. As Abu Qays lies on the ground, he feels his heart beating beneath him, imagining it as emanating from within the earth "pushing its way to the light from the deepest depths" (7). Kanafani melds birthing and sprouting, juxtaposing the fruits of a man's relationship to his wife with those of Abu Qays to his land. Kanafani's anthropomorphizing of the land intimately connects humanity to the earth, to cultivation, to reproduction, and to kinship. The veins of the body, the water running through the river, and the roots in the land all conceptually overlap in a tangle of images. This scene is one of origins, geographical, biological, and historical fused together. As Abu Qays listens to his heart in Shatt al-'Arab, he flashes back to the olive grove he cultivated before 1948. Kanafani gives aura a physical incarnation, in the body of the wife, the smell of her hair, the dampness of the earth. Kanafani makes aura tangible, breathable, graspable. But Kanafani makes clear that the birth of this feeling comes into relief at the moment of its loss, precisely in 1948, when Abu Qays is displaced from his village.

The "real time" of Kanafani's novel, the present tense of the narration, is August 1958. Siddiq associates 1958 with the formation of the United Arab Republic, when Egypt and Syria joined together, "one of the highest watermarks in the tide of Arab nationalism" (16). 1958, however, is associated with a more immediate frame of reference, a historical context generally overlooked in analyses of Men in the Sun. The characters arrive in Iraq only a month after 'Abd alKarim Qasim's July Revolution, a pivotal moment in the emergence of the oil economy. Qasim was a key in forming the Organization of Oil Producing Countries (OPEC) in 1960, an alliance that seemed to confirm a hostility toward Arab nationalism. The agreement of three Arab countries (Iraq, Kuwait, and Saudi Arabia) with Iran and Venezuela appeared to thwart one of Arab nationalism's primary aims: distributing oil profits across the Arab world (Yergin 509-23). ${ }^{14}$ Yet the 
close relationship between Arab nationalism and OPEC would be born out in the course of future conflicts with Israel, in 1967 and 1973 for example. Although though Men in the Sun sets up the mercenary oil economy as opposed to the aura of Arab nationalism, they are contingent phenomena.

Kanafani connects roots in the land to the oil economy, further playing on the word irq (meaning vein, root, or race). This punning alludes to the novel's setting in Iraq, a name that means "deep-rooted"; Iraq is considered one of the two civilizational "roots" (al-iraqanı) that grew out of the Mesopotamian area, one Persian and the other Arab. Abu Qays wants to buy one or two shoots ('irq aw 'irqayn) to plant for his two sons, imagining Kuwait is populated by trees (14, 16-7). Kanafani takes the weight of this civilization, incarnating it in the growth of the child. The dream is that these primordial roots will find their fruition in the oil economy; Kanafani sees petroleum revenues as essential to the survival of the Palestinians, as a lifeline to the dispossessed. Yet rather than a flourishing in these desert economies, Kanafani finds deracination and alienation-a theme terrifyingly developed in future oil novels. ${ }^{15}$ Although the organic filiation of an agrarian society and kinship bonds are contrasted against the affiliative ties of the capitalist economy, Kanafani uses analogous images to depict these new relationships. He describes a rite of passage into the mechanical age, as the novel's anti-hero is born from the belly of a tanker. Although depicted in negative relief against the novel's earlier organic birthing images, this "mechanical reproduction" parallels the earlier scenes in uncanny ways.

The shift from to mechanical reproduction is a shift in world orders, from naturalistic affective ties to relationships based on purely material interest. Like Weber's communal versus associative, or Said's filiation versus affiliation, one is based on race and culture and the other, on economic and class interest. According to Weber, communal bonds are exemplified by family and are emotional and traditional. Associative relationships are epitomized in free market exchange and based on self-interest, agreement "oriented purely to the promotion of specific ulterior interests, 
economic or other" (Said 1983, 118-19; Weber 40-1). Mercenary relationships take over in Men in the Sun's centrally situated fourth chapter, "The Deal." In this chapter, the "men in the sun" make a deal with the driver of the tanker who will smuggle them into Kuwait. Kanafani describes the "gang of men" as an 'asabah, which can also signify federation or league. Through this word, Kanafani evokes a traditional word that refers to the ties of the tribe, and the sense of "racialism, clannishness, tribalism, national consciousness, and nationalism" (Wehr 720). Ibn Khaldun's sociological treatise al-Muaqqadimah defines 'asabah as "group feeling that results only from blood relationship or something corresponding to it" $(97,98)$. Arab nationalism, which used socialism to argue for a sharing of oil profits, was built on the possibilities of this group feeling.

The shift to the new order of affiliative relationships is presented as antagonistic to filiative relationships. They are situated in different chronologies, one of a past legitimacy and the other as a menacing future. But they coexist in the narrative through temporal splicing, the juxtaposition of character types, and analogous imagery. This is exemplified in a scene that parallels, in a negative way, Abu Qays's reveries that open the novel. As'ad is of a younger generation, in his twenties, already accused of some political treachery. This will be compounded by his betrayal of his own family, his uncle who shelters him and his cousin betrothed to him. His uncle provides him with the money to travel to Kuwait, "the fruits of a lifetime," with the understanding he will come back to marry his cousin Nida. The youth reacts with rage, violence, and hatred toward the uncle, rejecting the idea of ever getting married (27). He bitterly reflects that his uncle

wants to buy him for his daughter like he buys a sack of manure for a field. He grasped onto the money in his pocket and got ready to jump up from his place. But when he touched it there, in his pocket, warm and smooth, he felt that he was holding on to the keys of his whole future... he tightened his fingers around the money rolled up in the pocket of his pants (28). 
As'ad's hostile perspective on marriage is laced with misogyny, as the language used to describe his anger (haniq) also denotes hatred of women. His attitude starkly contrasts with Abu Qays's feelings toward his wife. Both scenes employ similar metaphors: of wife as a fertile ground, as a field to be planted. Even the name of As'ad's cousin — Nada, meaning “dew," mnemonically evokes the dewy earth of Shatt al-'Arab, likened to Abu Qays's wife's wet hair. With As'ad, however, the smell of damp ground $(7,8,18)$ gives way to the stench of a "sack of manure." As'ad finds his role as fertilizer for this field repugnant, an "insult" (27). Instead, he displaces his gratification onto another object: money. In this passage, As'ad exchanges Abu Qays's "throbbing little bird between the palms of the hand" for the warmth of smooth coins. Touching the money in his pants, Kanafani turns it into a masturbatory scene, as As'ad concentrates on satisfying himself alone.

Kanafani continues the sexual and mercenary images in the driver, Abu al-Khayzuran. At the border, the guards tease Abu al-Khayzuran about his relations with a prostitute Kawkab ("planet”). Most analyses of the novella suggest that the scene is ironic, given the fact of Abu al-Khayzuran's emasculation in 1948 ('Ashur 67, Shukri 249). But the prostitute epitomizes the relationships in this new land, based not on affective ties, but on the mutual alignment of economic interests, an “association between exchanging parties" (Weber 43). Just as Abu al-Khayzuran lies in bed fantasizing about money, so he fantasizes about the prostitute (94). The jokes about Kawkab occupy the narrative's most critical moments, as the men outside slowly perish in the burning heat of the airless metal tanker. The reader is agonizingly aware of the men's life trickling away as the empty banter drags on. The "joke" is that the prostitute loves Abu al-Khayzuran so much that she gives him checks and money, making the smuggler a kind of pimp. The smugglers in Basra accuse each other of being "pimps" (qawawid), in Arabic, a pun on the word "driver" or "leader." 16 The scene at the border returns to the sense of the drivers as pimps, trafficking in human bodies, epitomizing the mercenary relationships dominating this new terrain. 
When As'ad asks the driver Abu al-Khayzuran, "Why do you smuggle?" He answers, "I just want more money... more money... more money... I've found that it's hard to accumulate wealth by means of training and education... Do you see this vulgar creature that is me? I own some money!" (72). After this conversation, Abu al-Khayzuran opens his tanker up to the men, the vehicle he uses to smuggle human cargo across the border. By opening up the tank (khazzan), he metaphorically opens the coffers (kbizana) of Kuwait to the men. By entering into the tank, they become the hopeful initiates into money and wealth. Abu al-Khayzuran's name itself puns on khazzan/ khizana, as Kanafani uses paronomasia, a classic technique in Arabic letters. It is also a comment on lost masculinity compensated for with materialism: Abu al-Khayzuran's name means "owner of the hollow reed."

Kanafani draws on classic symbols of passage in the form of the journey, desert, hell, birth, and death, as the men literally try to pass into another state. Siddiq likens "the half-naked dive into the infernally dark belly of the empty water tank" to a "rebirth" (12). As Abu al-Khayzuran stands panting:

The open mouth of the tank remained throbbing with the void... A drop of sweat falls from his brow on the roof of the iron tank and immediately dried... He bent his wet back until his face was on top of the black hole and he shouted with a dry, wooden voice... He put his two stiff hands on top of the edge of the mouth and supporting himself with his two strong arms, he slid himself inside the tank (97).

Kanafani's images are strangely sexual, with Abu al-Khayzuran gasping, convulsing, and sweating over the empty hole, bending his wet back on top of the mouth and finally, sliding himself inside. When he discovers that the men are dead, "He feels he is about to choke... he began to feel that he was anointed in a heavy oil... covered in this oil on his chest and back" (98). At this point, the sexual image metamorphoses into a birth, as "he began to shake his head with violence as he begot 
[himself?] from the hole." This is a monstrous scene: the sterile Abu al-Khayzuran single-handedly procreating himself from the metal womb of the truck, the counterpart of As'ad masturbating his money. It is reproduction in the mechanical age, as the driver emerges from the steel mouth, anointed in oil. Kanafani depicts the birth of the rapacious oilman while the three immigrant men lay dead in the belly of the truck, stillborn. The men perish on the outskirts, the workers languishing on the periphery of a consumer society. From their suffering and sweat, the new man Abu alKhayzuran emerges. This is a sterile world order, born out of commerce between pimps and prostitutes.

Men in the Sun begins with organic images of birthing and ends with a virtual abortion. The machine presides over-and embodies - the ritualistic state of transition to the industrial age, signaling the passing of the agrarian order. Kanafani reconstructs tradition that appears as not only "dead and buried...but murdered and still remaining, as Gayatri Spivak has suggested, inappropriately and insufficiently mourned. It is a tradition that has become alien and distant, a marginal and threatened fragment of life, but a fragment out of whose lineaments one might attempt to recall what was once all of life. These collectively come to acquire the auratic name of religion" (Mufti 878). The novel creates this aura only to destroy it, reproducing the conditions of secular modernity. Although Kanafani, like Munif, was a secularist and Arab nationalism is essentially a secular creed, religious imagery inflects their climactic scenes. As the men pass through the desert, they cross into a supernatural realm, headed toward the "next life." The 150 kilometers of $\mathrm{road}$ at the border is described as the path God promised "before he distributed people between heaven and hell. For whoever falls on the path goes to hell and whoever crosses it arrives in heaven. And the angels here are the men of the border!" (66). The desert is an inferno, the other world (al-akbirah), a hell (jabim, jahannim), blaze (wahaj), flame (lahab), burning (ibtiraq), fire (nar), flaming ground (ard multabibab) (7, 8, 25, 27, 65, 66, 67, 72, 74, 86, 88). The border guards call Abu al-Khayzuran "damned" six times, 
having committed the seven sins, lied, and deceived them (93-5). Down the road, he returns the curse, invoking not Allah, but al-ilah, "the god," in a pagan sense: "Curse of the god almighty on you, curse of the god that doesn't exist at all in any place... curse of God on you all of you" (96-7). The dream of "umbrage" — of shade and protection— has turned into a burning inferno for the men. The steel womb of the tanker thus forges the denizen of the world economy, what Sayyid Qutb calls the "deformed birth" of the technological age, or Marinetti "the dreamed-of metallization of the human body," a violent machine whose "lifeblood is oil" (Qutb 12; Benjamin 121; Williamson 748).

\section{Paradise Lost: Cities of Salt}

Like Men in the Sun, Munif's Cities of Salt is an “epic of a world abandoned by God," Lukács's definition of the novel (20). Cities of Salt begins in epic terms, as a world not yet abandoned, as a paradise not yet lost. The text opens with Wadi al-'Uyun (Valley of the Springs), a place the travelers call "paradise on earth," a place of sweet waters, cool breezes, palm groves and abundant green (20). Munif infuses the place with a sense of the divine: the wadi is "shay khariq," something preternatural, miraculous, transcendent, beyond the rational. The travelers in the caravans are "sure that That which had created the world and human beings had created, at the same time, Wadi al-'Uyun... to be a salvation from death in this treacherous, accursed desert... a blessed power protects them and makes life prosper" (19). In recounting the tribe's genealogy, their common ancestor is described: "the selflessness that distinguished all his movements and existence made him, in the eyes of the whole, khariq, transcendent." The word used by Munif to express this selflessness, tafanin, is also a mystical term denoting the obliteration of the self and extinction of individual consciousness in the whole. The author sustains the Sufi terminology with the travelers' "insistence on the repetition [dhikr] of Wadi al-Uyun... [as] salvation." This is what Lukács describes as a "transcendent locus" (20), or what Carrera calls the "sitio clave" (98) or how Kanafani describes "Iraq." These are 
repositories of social ideals, embodied in geographical space, emanating a sacred aura. As Frederic Jameson observes, "The novel can express a kind of unity of meaning and life, but it is a unity thrust into the past, a unity remembered only" (176).

Munif's descriptions of the oasis resonate with nostalgia for the desert and the past, idealizations that are partially a product of his own exile. The features of the wadi echo with the utopian vision of later classical Arabic poetry, where poets, separated in time and space from their cultural origins, imagined an idyllic landscape in Najd as a kind of Arcadia. The landscape resemble the mythical Najd, with a high plateau, seasonal streams, "several springs that form oasis like ponds surrounded by vegetation," and people who are hospitable, humane, and virtuous. "This is pure idyll. As a landscape, Najd has become transformed into an arrested poetic vision. It is the desert abloom in the poet's memory long after the rain of spring is lost in vaporous figments of mirages and long after the desert has reverted to its nearly year long inclemency" (Stetkevych 117, 121).

The "adequate balances" of the epic are central to Munif's descriptions of the wadi, cycles dictated by water, by winters and summers, floods and droughts, abundance and scarcity (Lukács 33). Time is measured by cycles: years of blessings and years of drought, of floods and locusts, of caravans' comings and goings. In Munif, a social and economic equilibrium is struck in the community, as all suffer in leaner times. The cycles of poverty and wealth collectively shape the physiques of the people of the wadi, making their features symmetrical. The community is also described as one body, with a sense of proportion between its individual members. These cycles are governed by water, the gold ibn Sa'ud originally hoped that the Americans would find. Munif expresses this harmony through a number of synonyms: ittisaq, tanasuq, and insijam. Insijam, for example, suggests fluency and streaming, a metaphor Munif sustains by describing the people's faces "flooded with life" (28). Water shapes their communal rhythms and time is lived as ebbing and flowing, a contrast with the exponential growth of the oil boom. In the years of abundance, khayr, or 
"goodness," the wadi's inhabitants overflow with generosity, while in the years of drought, they withdraw into themselves with a certain introversion and melancholy. These cycles also affect the balance between the sedentary and nomadic. In times of want, the wadi cannot support its own population, forcing people to emigrate in search of wealth. "The people of the wadi are like their waters..." (23). Through this picture, Munif describes the historical social and economic organization of the Arabian peninsula, where trade conducted by the nomadic Bedouin balanced out the food produced by the sedentary, agrarian oasis dwellers. All this serves as contrast to the exponential growth of the oil boom.

Like Kanafani, Munif maps anthropomorphic traits onto the land (and vice versa), describing a "place pouring out green, as if it exploded from the belly of the earth... one of the few ways in which nature expresses its genius and willfulness" and a people "planting themselves in the land" (19). The author develops this relationship in a scene of planting, as one of the wadi's inhabitants, Mit'ab, "feels more than any other time the bonds tying him to the land and palms and fig trees and to the people of the wadi, too" (65). Like Kanafani, he imagines infants as seedlings, as Mit'ab points out to his son:

That palm, the fourth on the right, is your same age, my son. Every day you grow, it grows with you. Soon you will plant a palm for your own son and your own son will plant a palm for his son. Year after year the wadi will become greener, and people will keep passing through, drinking the wadi's water, asking for God's mercy on the dead, and they'll say, while in the shade (zill) of the tree, God have mercy and on all those who have planted a palm and a green shoot (65).

Munif describes the sprouting of the plants as a birth, as Mit'ab watches his garden bloom after the rains. 
It gave him pleasure to watch the water drip into the earth and remain there. Then the earth began to do incredible, unfathomable things... The earth trembled a prolonged tremor, closer to a shudder, and the belly of the earth began to spill out. He saw the seeds that had been scattered begin to force their way out from inside the earth, raising their little heads... this shudder of the earth... resembles the cleaving between a man and a woman, resembles the moment of ecstasy that a human feels $(81) .{ }^{17}$

The agrarian ties do not just bind generations to this locale, invested as they are in the planted earth, they also tie the community together, making water thicker than blood. They tend each other's gardens, making "the people as if they were one family. It's true that family relationships of some kind or another brought people together here, but the relationships that dominated were stronger than those family ties" (72).

When the Americans come to the oasis, they raze the palms and drive out the inhabitants. Munif personifies the trees, as if they were living beings felled from the earth: they kneel in supplication, begging mercy from their executioners. The author depicts them imploring with a voice, feeling pain, needing and wanting. Munif paints the violence of this severing in palpable, human terms, with anthropomorphic images of the trees as living flesh torn from the ground.

The tractors attacked the trees like hungry wolves, tearing them up and throwing them to the ground one after another, and after than, leveling one tree after another, between the irrigation canal and the land around it. Even if they finished with one group of trees, it attacked with the same voracity and ferocity a new group and began to uproot them. The trees, leaning and reeling, before falling, screamed, begging for help, wailing, frantic, calling a final painful call, until they neared the ground, falling beseechingly, as if they needed or wanted to cling to the ground, in an attempt to spring or burst forth from the ground again (122). 
Munif depicts the machines' attack on the trees as a battle between two factions, but even the machines are depicted as living entities, like "huge moving iron creatures" (113). Like the voracious "mouth" of Abu al-Khayzuran's truck, these machines have appetites of wild beasts and devour human flesh. Both authors depict a twofold process: the initial uprooting of the people from the land, then the transformation of these people into fuel for the machines. Not only do they represent the transition to a society constituted by machines, but the demand for labor to sustain their functioning. The people of the wadi feel that "the world had ended" (114).

As the people are severed from their homes and land, Munif resorts to apocalyptic language. With the destruction of the wadi, the infernal qualities of the desert take over. Fueled by the summer heat, it transforms into "an unbearable hell... and torment" (98). With the Americans' arrival, the people of the wadi are already beset by premonitions of evil, referring to them as 'afarit (devils), jinni (demons), and shayatin (satans) $(56,58,59,61,62,87,96,99,103,110,121)$. When the Americans begin to pour water into the ground-drilling through the ground rock-the people of the wadi wonder if they are "quenching the thirst" of the jinn "burning in the belly of the earth" (151). Through these images, Munif constructs an antithetical world of hellfire, diametrically opposed to the "paradise" that Wadi al-'Uyun had been. Munif speaks in a prophetic voice, warning of hellfire, of the ethical and moral ramifications of these seismic disruptions. He describes a fervent heat in this "house of fire"; people feel this burning as an intense pain, tearing apart certain limbs of their body (223). Mit'ab says, "They talk about resurrection day? Today is resurrection day. They say if iron strikes iron? Today I saw iron strike iron" (86-7). The people live through hellfire, are nearly destroyed, and are re-forged into a new form. In Munif's apocalypse, men are not turned into salt, but into machines.

In his book Democracy First, Democracy Forever, Munif explains the apocalyptic imagery of the title Cities of Salt. It refers, he says, to unsustainable cities that would turn into "infernal ovens" 
without a constant flow of electricity and air conditioning. He describes these steel edifices as a world of "huge iron entities" molding humanity in its image (327-8). In a key, hallucinatory scene in the novel, an American, a black man, works to erect a drill. As night turns to day, he transforms into an iron pillar, a kind of modern day "pillar of salt." When the men from the wadi begin working for the American company, the author describes one of them as "planting himself in Wadi al-'Uyun, not like the palms that used to fill the wadi in days past, but like those iron pillars sunk in every place" (146). In an interview in Counterpunch, Munif explained the title's meaning to Tariq Ali, "Cities of salt means cities that offer no sustainable existence. When the waters come in, the first waves will dissolve the salt and reduce these great glass cities to dust. In antiquity, as you know, many cities simply disappeared. It is possible to foresee the downfall of cities that are inhuman."

Aamir Mufti attributes "auratic criticism" with postcolonialism, but this discourse inflected with religiosity is similarly found in the imperial metropolises. This is precisely Raymond Williams's point when he argues that what happens in the metropolitan economy "determined and was determined by what was made to happen...first the local hinterland and then the vast regions beyond it, in other people's lands. This creates new dependent relationships between all the industrialized nations and all the other 'undeveloped' but economically important lands." This is the system, he writes, "we now know as imperialism" $(279,280)$. Upton Sinclair, in his own novel about oil in 1926, wrote in similarly morally stark terms. Like Cities of Salt, Oil! also details specific historical events, using thinly veiled disguises for the principal players. Detailing the scandals marring the Harding administration, namely, bribes paid for control over the California oil concessions, Sinclair concludes the novel warning of "an evil Power which roams the earth, crippling the bodies of men and women, and luring the nations to destruction by visions of unearned wealth, and the opportunity to enslave and exploit labor" (527). In the Saturday Review of Literature, Walter Lippman would label the author an "apocalyptic socialist" for this "messianic," moralizing streak. This vision 
of a doomed society, plagued by a corrupt materialism, "is a dream which recurs again and again throughout history as the religion of small minorities who cannot endure the life of their times. This religion never conquers the world until it renounces its own essence, becomes worldly, and ceases to demand all it once held to be important." In this respect, Sinclair cannot be a modern novelist in the proper sense, still mired in the conscience of an earlier age (in religion), not yet inculcated into the secular materialism of (worldly) contemporary society. Lippman offers these pieces of advice: to stop being "afraid of money," and "barricad[ing] himself from the world." Munif begins Cities of Salt as an apocalyptic socialist, depicting an agrarian society, working as a community, equally sharing labor and responsibility. The end of this world is depicted as a spectacular fall from grace.

In Raymond Williams's study of the relationship between country and city, he describes the nostalgic golden ages continually constructed by successive literary generations. "The emphases on obligation, on charity, on the open door to the needy neighbour, are contrasted, in a familiar vein of retrospective radicalism, with the capitalist thrust, the utilitarian reduction of all social relationships to a crude moneyed order. This leads to an evident crisis of values in our own world. The retrospective radicalism... is often made to do service as a critique of the capitalism of our own day: to carry humane feelings and yet ordinarily attach them to a pre-capitalist and therefore irrecoverable world" (35-6). Kanafani and Munif are proponents of this retrospective radicalism. Yet their paeans to their roots lend their narratives humanity and anchor them in native soil. They perceive the crisis of the industrial age — and foreign presence in indigenous land — as apocalyptic, but some survive. The resulting technology makes their narratives possible, not just in the sense of publication and distribution, but it is the very tale they tell.

When Cities of Salt was translated into English, it was widely reviewed in the US literary press. ${ }^{18}$ Francine Prose of the New York Times writes that reading Cities of Salt "is like seeing carved shutters thrown open or an embroidered veil drawn back, and glimpsing behind it the face of 
someone very much like someone we know." She intends that an orientalist veil has been rent, humanizing "the Arab as the unknowable Other." Yet she strikes on one of the novel's core truths: the contemporary history of Saudi Arabia was created by American enterprise. The first volume of Cities of Salt concludes with the 1953 workers' strike against Aramco in Dhahran, a piece lifted from history, like so much of the novel. Munif builds up to the strike by describing a system of segregation that Prose describes as "eerily familiar" to Americans. Oil historian Robert Vitalis chronicles “a system of race and caste segregation in [Aramco's] zone of operations in Dhahran... institutions and norms of separate and unequal rights and privileges, of crude racism and progressive paternalism" (Vitalis 1997, 17). A CIA report on the strike observes parallels with civil rights strikes at home, acknowledging severe disparities between classes and races (with orientalist imagery thrown in). The report contrasts a "primitive land of low pay, slaves, eunuchs, and harems to the comfortable conditions of US residents in Dhahran [Aramco's headquarters]" (Vitalis 1997, 17). The language of the document is revealing, not only projecting the United States' history of slavery onto new territory, but reproducing its fraught city/country, North/South, free/ slave relationship in the desert. The tale is part of the American legacy in other, unforeseen ways, as a history of tribes uprooted and displaced, of segregation, and cheap, imported labor. ${ }^{19}$ Kanafani's Men in the Sun similarly echoes recent immigration history in the US. His tale is retold with the recent fate of 19 Mexicans who suffocated in a truck, as they were being smuggled across the border (Hegstrom and Feldstein 2003). It is not surprising that the American University of Cairo recently banned Cities of Salt. The incident was reported as an example of Egyptian censorship (and of stifling criticism of ruling regimes) ${ }^{20}$ A new edition of Cities of Salt, issued by the Egyptian publishing house Maktab alMadbuli, is available a block down from AUC at Madbuli's bookstore.

Like Prose, John Updike found "Munif's Muslims... familiar," though he compares them to the "noble caftaned savages admired by T.E. Lawrence" (199). He calls Munif-“though he lives in 
France and received a Ph.D. in oil economics from the University of Belgrade-insufficiently westernized to produce a narrative that feels much like we call a novel" [my italics]. Using derogatory language of insufficient development, Updike touches on the oil novel as both product of and protest against an imported imperial modernity. Updike scoffs at the novel's "single insistent sociological point" that "the Arabs are discomfited, distressed, and deranged by the presence of Americans in their midst." Ironically, Updike's recent novel Terrorist apparently treats the same sociological point, but in the context of New Jersey. Robert Stone's review in the New York Times Book Review comments on "Americanization" as an exported imperial modernity, themes that resonate uncannily with Cities of Salt. Of “Americanization," Stone writes:

In dystopic usage the suggestion was of quick greenbacks primitively acquired by new money, the ruthless subjection of the land and the aboriginal people, and all the confusion and suffering and mess wrought by mines, railroads and factories. The term invokes the transformation of the landscape into unnatural mechanical shapes... Most threateningly for many, 'Americanization' also meant a setting aside of the social order in ruthless pursuit of profit, a jury-rigged class system based on money, a rootless and dislocated population.

The double history of the United States and Saudi Arabia reveal their intimate imbrications through these literary works, their overlapping motifs, patterns, and themes. In this sense, these two seemingly disparate cultures are not only brought together by the petroleum industry, but also by the global technology of the novel. This poses problems for Benedict Anderson and others' identification of the novel as an expression of the imagined community of the nation. Is it, instead, the vehicle for empire imagined on the ground? Others, namely Said, have argued as much. Although Munif dreams of unsullied origins, his work reproduces the mechanics of modernity and in so doing, gives birth to itself. If it is a deformed birth, as in Updike's estimation, then it all the more reflects the damaged and fallen state that is the modern world. Even the dream of pure 
origins - that has become the staple of Islamism - is a product in that sense, of the alienating and dislocating effects of modern existence.

Although Munif and Kanafani were Arab nationalists, meaning they were socialist and secular in political orientation, their apocalyptic imagery imparts their work with a religious hue. Their belief about the inherently destructive power of the industrial revolution resonates widely in the Arab and Muslim world. In a recent Islamist conference, Camilia Hilmi observed that "scientific progress and technological competition... will not be realized except on the rubble of morality, belief, and commitment to the dictates of Islam" (11). Kanafani and Munif mourn what Benjamin calls the "liquidation of the value of tradition in the cultural heritage," yearning for lost origins, authenticity, permanence, and ritual (104). Paradoxically, it is precisely through this loss that they become modern novelists; through this destruction, an authentic past is produced and the phantasmagorical dream invented. Instead of catharsis or emancipation, however, they experience a liquidation and enslavement by the empire of the machine.

${ }^{1}$ The term "empire of the machine” comes from Gustavo Luis Carrera’s Novela del petróleo en Venezuela (The Petroleum Novel in Venezuela). He discusses the contrast between the traditional environment and the petroleum explosion: "Lo que resulta más evidente como primera impresión en la 'explosión' petrolera es el contraste entre el ambiente tradicional y el nuevo estado de cosas después del surgimiento inesperado" (79).

${ }^{2}$ Upton Sinclair's Oil! (1927) imagines the righteousness of country life corrupted by oil politics. (Paul Thomas Anderson's film There Will Be Blood based on the novel is clearly intended as political allegory.) Carrera's work on the Venezuelan petroleum novel details the disruption of an agrarian existence; Laura Restrepo's novel La novia oscura (2002) imagines an early utopia of the petroleros in Colombia; J.M.G. Le Clézio's Onitsha (1991) is full of images of sacred waters in Nigeria, before their sullying in foreign hands. 
${ }^{3}$ While Lukács (1996) and Benjamin (2002) saw aura as part of prior forms, like the epic or painting, that was destroyed by mass production, Jameson's work on utopia sees aura as one more product of mass culture (1979).

${ }^{4}$ A simplified transliteration system has been used, with ' for the 'ayn and ' for the hamza.

${ }^{5}$ Sabry Hafez discusses debates over the authenticity of imported genres like the novel in The Genesis of Arabic Narrative Discourse: A Study in the Sociology of Modern Arabic Literature (11-23).

Aamir Mufti defines "aura of authenticity" as "a pervasive language and mood in the contemporary critical scene that is concerned with the inauthenticity of postcolonial culture, community, and politics, and in which authenticity comes to attach itself to the concepts of certain cultural practices as a kind of aura" (87-8).

6 "The new petroleum order displaces man from the key site that he occupied in the traditional, agrarian economy and implants there the machine."

7 “The America That I Saw: In the Scale of Human Values” records Qutb’s impressions of the US after two years (1948-50) spent studying in Greely, CO. He published a series of articles in al-Risalah (November 5, 1951), reproduced in Salah 'Abd al-Fattah al-Khalidi's Amrika min al-Dakbil: Bi Manzar Sayyid Qutb [America from the Inside: From Sayyid Qutb’s Perspective]. A translation can be found in Kamal Abd al-Malek's America in an Arab Mirror: Images of America in Arab Travel Literature $(9-27)$.

${ }^{8}$ Benjamin's italics.

${ }^{9}$ Using Benjamin as a framework, Mufti observes that the destruction of tradition is like a murder: "The question of tradition takes a distinct form, with the past appearing not exactly to be dead and buried, even if present in ghostly form, but murdered' (87).

${ }^{10}$ Shakir Nablusi, in a work on Munif, argues that the Gulf novel could only come into being with an imported bourgeoisie, a class whose wealth, ennui, and intrigues are documented in this literature 
(195). For a brief discussion of some of the authors of the oil novel, see Shukri Muhammad 'Ayyad's article "al-Misriyyun fi al-Ghurba" [Egyptians in Exile].

${ }^{11}$ One of his first novels, Sibaq al-Masafat al-Tawilah (Race of the Long Distances, 1976), criticized the CIA's assassination of the Iranian Prime Minister Mohammed Mosaddegh, who had worked to nationalize the oil industry. His doctoral thesis from Belgrade University was on petroleum; he worked for the Syrian Oil Company and edited the journal al-Naft wa al-Tanmiyyah (Oil and Development) in Baghdad (Munif 1994, 400).

${ }^{12}$ Maps, documents, and photographs can be found at ARAMCO, “Tapline,” http:// almashriq.hiof.no/lebanon/300/380/388/tapline/. Wadi al-'Uyun (Munif's fictional locale) means "valley of the springs" and Abqaiq (the actual Arabian oasis) means "springs." Manifold textual indicators link Wadi al-'Uyun to Abqaiq, among them Munif's descriptions of its proximity to Aramco's headquarters and to the company's port in Ras Tanura.

${ }^{13}$ Earth is feminine and Kanafani uses its gender to play on the sexual imagery. Roger Allen writes about a similar personification of the earth as a woman and as possessing a heart in a short story by Kanafani. "In Ma Tabaqqa la-Kum (What is Left to You) Hamid throws himself to the ground 'and felt it like a virgin trembling beneath him, as a beam of light silently and softly swept across the folds of sand...' In another telling juxtaposition, the beats of the earth beneath Hamid's prostrate body find themselves associated with the fetus inside his sister's womb” (149).

${ }^{14}$ For an extended discussion of Qasim's tensions with the Pan-Arabists, see Eric Davis's Memories of State: Politics, History and Collective Identity in Modern Iraq (186-201).

${ }^{15}$ A prime example of this is Ibrahim 'Abd al-Majid's al-Balda al-Ukhra (The Other City, 1988), a surreally brutal portrait of an Egyptian's experience working in Tabuk, Saudi Arabia.

16 'Ashur suggests that Kanafani blames the Palestinians' situation on the leaders in the Arab world, since the word qa $i d$, driver, can also mean "leader." She writes that Abu al-Khayzuran is "the 
driver/ leader on the journey of ruin. Perhaps he possesses good intentions, but in any case he carries his charges to their death. This is the leadership that does not fulfill its promises or responsibilities. Abu al-Khayzuran is a symbol of the leadership of the Palestinian people that failed during the nakbah and right after it. Perhaps this is also an indicator of the Arab leadership, the Arab kings and presidents during the period of 1948" $(69,70)$.

${ }^{17}$ This passage echoes Qur'an 22: 5: 'We created you from dust, then a drop of semen, then an embryo... You see the earth all withered, then We send down rain upon it, and it bestirs itself, swells, and brings forth every kind of beauteous verdure."

${ }^{18}$ Ammeil Alcalay's "Gulf States of Mind..." reviewed Munif for the Village Voice (11 June, 1991): S15, as did Amitav Ghosh, "Petrofiction" New Republic (2 March, 1992): 29-34, and David Gilmour, "Desert Ruritania” New York Review of Books (26 March, 1992), 19-20.

${ }^{19}$ The battle over native rights and oil drilling in Alaska is currently raging, see LaDuke (2003) and Democracy Now! interview with Alaskan Gwich'in activist Sarah James.

${ }^{20}$ See the Human Rights Watch report The Repression of Academic Freedom in Egyptian Universities, as well as Judith Gabriel's and Nadia Abou El-Magd's articles in the Arab press.

\section{WORKS CITED}

'Abbas, Ihsan, Fadal al-Naqib, and Ilyas Khuri. Ghassan Kanafani: Insanan, Adiban, Munadilan [Ghassan Kanafani: Human, Author, Fighter]. Beirut: Manshurat al-Ittihad al-'Amm lil-Kitab wa al-Sahifyin, 1974.

'Abd al-Majid, Ibrahim. al-Balda al-Ukhra [The other city]. Cairo: Maktab Madbuli, 1988. Abou El-Magd, Nadia. “Censorship Board on a Banning Spree.” Al-Abram Weekly (18-24 March, 1999).

Allen, Roger. The Arabic Novel: An Historical and Critical Introduction. Syracuse: Syracuse UP, 1995. 
Anderson, Benedict. Imagined Communities. New York: Verso, 1983.

Anderson, Paul Thomas. There Will Be Blood. Paramount: December, 2007.

'Ashur, Radwa. Al-Tariq ila al-Khaymah al-Ukhra: Dirasah fi 'Amal Ghassan Kanafani [The Road to the Other Camp: A Study of the Works of Ghassan Kanafani]. Beirut: Dar al-Adab, 1977.

'Ayyad, Shukri Muhammad. "al-Misriyyun fi al-Ghurba" [Egyptians in Exile]. Al-Hilal Jan. 1993: 34-41.

Benjamin, Walter. "The Work of Art in the Age of its Technical Reproducibility." Walter Benjamin: Selected Writings. Vol. 3. Trans. Edmund Jephcott et al. Ed. Howard Eiland and Michael W. Jennings. Cambridge: Harvard UP, 2002.

Carrera, Gustavo Luis. La novela del petróleo en Venezuela. Caracas: 1972.

Davis, Eric. Memories of State: Politics, History and Collective Identity in Modern Iraq. Berkeley: University of California Press, 2003.

Gabriel, Judith. "International Debate Flares over Book-banning at AUC." Al-Jadid: A Review and Record of Arab Culture and Arts 5:26 (Winter, 1999).

Hafez, Sabry. The Genesis of Arabic Narrative Discourse: A Study in the Sociology of Modern Arabic Literature. London: Saqi, 1993.

Hilmi, Camilia. "Opening Word.” Tahrir al-Mar'ah fi al-Islam [The Liberation of Woman in Islam]. Kuwait: Dar al-Qalam, 2004.

Human Rights Watch. Reading Between the "Red Lines": The Repression of Academic Freedom in Egyptian Universities (June, 2005).

Jameson, Frederic. “The Case for Georg Lukács.” Marxism and Form. Princeton: Princeton University Press, 1971. . "Reification and Utopia in Mass Culture." Social Text 1 (1979): 130-148.

Kanafani, Anni. Ghassan Kanafani. Beirut: Palestine Research Center, 1973. 
Kanafani, Ghassan. Rijal fi al-Shams. Beirut: Manshurat al-Tali'ah, 1963.

. Men in the Sun and Other Palestinian Stories. Trans. Hilary Kilpatrick. Boulder: Lynn

Rienner, 1999.

Le Clézio, J.M.G. Onitsha. Paris: Gallimard, 1991

Lukács, Georg. The Theory of the Novel: A Historico-Philosophical Essay on the Forms of Great Epic

Literature, trans. Anna Bostock. Cambridge, MIT Press, 1996.

Marinetti, Filippo Tommaso. "Four Post-Modernizations.” Futurist Manifesto.

$<<$ http://www.cscs.umich.edu/ crshalizi/T4PM/ futurist-manifesto.html $>>$

Mufti, Aamir. "The Aura of Authenticity." Social Text 18:3 (Fall, 2000): 87-103.

Munif, 'Abd al-Rahman. Cities of Salt. Trans. Paul Theroux. New York: Vintage, 1989.

—. Al-Dimuqratiya Awlan, al-Dimuqratiya Da'iman [Democracy First, Democracy Always].

Beirut: Jami’ al-Huquq al-‘Arabi, 1998.

-. Al-Katib wa al-Manfa: Humum wa Afaq al-Riwayah al-'Arabiyah [The Writer and

Exile: Concerns and Horizons of the Arabic Novel]. Beirut: al-Tab’ah, 1994.

. Mudun al-Milh. Beirut: Al-Mu`assasah al-'Arabiyyah lil-Dirasat wa al-Nashr, 1984-9.

- Sibaq al-Masafat al-Tawila [Race of the Long Distances]. Beirut: Al-Mu`assasah al-

'Arabiyyah lil-Dirasat wa al-Nashr, 1979.

Nabulusi, Shakir. Madar al-Sahra': Dirasah fi Adab 'Abd al-Rabman Munif [The Theme of the

Desert: A Study in the Literature of 'Abd al-Rahman Munif]. Beirut: Al-Mu`assasah al-'Arabiyyah lil-Dirasat wa al-Nashr, 1991.

Prose, Francine. "Sindbad in a White Rolls Royce." New York Times Book Review (27 October, 1991).

Qur'an: A Contemporary Translation. Trans. Ahmed Ali. Princeton: Princeton UP, 1993.

Qutb, Sayyid. “Amrika Allati Ra'ituha” [America That I Have Seen]. Amrika min al-Dakbil: Bi Manzar Sayyid Qutb [America from the Inside: From Sayyid Qutb’s Perspective]. Ed. 
Salah 'Abd al-Fattah al-Khalidi. Dar Madani: 2002.

. "America That I Have Seen: In the Scale of Human Values." America in an Arab

Mirror: Images of America in Arab Travel Literature. Ed. Kamal Abdel-Malak. New York:

Saint Martin's Press, 2000.

Restrepo, Laura. La novia oscura. New York: Rayo, 2002.

Said, Edward. Culture and Imperialism. New York: Vintage, 1993.

- The World, the Text, and the Critic. Cambridge: Harvard University Press, 1983.

Schneider, Luis Mario. 1997. La novela mexicana entre el petróleo, la homosexualidady

la política. México, D.F.: Nueva Imagen.

Shukri, Ghali. Kalimat min al-Jazirah al-Mahjurah [Words from the Abandoned Peninsula]. Beirut: al-Maktabah al-'Asriyyah, 1964.

Siddiq, Muhammad. Man is a Cause: Political Consciousness of the Fiction of Ghassan Kanafani.

Seattle: University of Washington Press, 1984.

Sinclair, Upton. Oil! New York: Grosset and Dunlap, 1927.

Stetkevych, Jaroslav. The Zephyrs of Najd: The Poetics of Nostalgia in the Classical Arabic Nasib.

Chicago: University of Chicago Press, 1993.

Stone, Robert. “Updike’s Other America." New York Times Book Review (June 18, 2006).

Updike, John. “Satan’s Work and Silted Cisterns.” New Yorker (17 October, 1988): 199.

Vitalis, R. “Aramco World: Business and Culture on the Arabian Oil Frontier.” The Modern

World of Business and Industry. Ed. K. Merill. Princeton: Princeton UP, 1998.

—. "The Closing of the Arabian Oil Frontier and the Future of Saudi-American

Relations." Middle East Report 204 (1997): 17.

Weber, Max. Economy and Society: An Outline of Interpretive Sociology. Eds. Guenther Roth and Claus Wittich. Berkeley: University of California Press, 1978. 
Wehr, Hans. Arabic-English Dictionary, ed. J.M. Cowan. Ithaca, NY: Spoken Language Services, 1994.

Williams, Raymond. The Country and the City. London: Oxford UP, 1973.

Williamson, Harold F., Ralph L. Andreano, Arnold R. Daum, and Gilvert C. Klose. American

Petroleum Industry: The Age of Energy, 1899-1950. Evanston, Ill.: Northwestern UP, 1959.

Yergin, Daniel. The Prize: The Epic Quest for Oil, Money, and Power. New York: Free Press, 1991. 